\title{
Trend and pattern of international capital flows in India
}

\author{
Soji M Sebastian ${ }^{1}$, N. Karunakaran ${ }^{2 *}$ \\ ${ }^{\mathbf{1}}$ Assistant Professor, ${ }^{2}$ Principal and Research Guide, ${ }^{1}$ Dept. of Commerce, EKNM Government College, Elerithattu, Nileshwar, Kerala, \\ India, ${ }^{2}$ Economics of Kannur University, People Institute of Management Studies (PIMS), Kasaragod, Kerala, India

\section{*Corresponding Author: N. Karunakaran} \\ Email: narankarun@gmail.com
}

\begin{abstract}
Foreign capital flows contributes an important role in the economic development of a nation. Sometimes due to the scarcity of domestic resources, a nation depends on foreign capital for its capital investment and economic development. It fills the gap between domestic savings and total capital investment requirement of the country. In India foreign capital investment is opened in almost all sectors. For some sectors it is restricted. The study focused on trends and patterns of foreign capital flows in India during 2000-01 to 2019-20. Sectoral distribution of FDI in India, share of top ten investing countries and state wise classification of FDI in India were analysed.
\end{abstract}

Keywords: Trends and pattern, International capital flows, Sectoral distribution, Investing countries, India.

\section{Introduction}

A developing country like India requires large financial resources to finance its developmental activities. Earlier the developmental activities were financed through domestically generated savings. Domestic savings originates from household sector, private corporate sector and public sector. But there was a large financial gap between the expected flows and what is actually needed by developing countries to achieve their development goals. This has necessitated the need for alternative source for financing developmental activities. The first sustained effort of the restructuring the economy for attracting the alternative source of finances came in response to the balance of payment crisis in 1991. The Government of India has reacted through significant macro-economic and structural changes. The domestic capital market was restructured. Interest rates were liberalized. The government also made easier for MNCs to invest in India. Recently, India welcomes foreign investment virtually in all sectors. As a result the quantum of foreign investment inflow to India has increased significantly (Rema R and Karunakaran N, 2019).

Foreign direct investment is considered as a vehicle through which new ideas; advanced technique, technologies, and skills are transferred across borders and provide substantial technologic progress for long run growth. FDI should be considered as an important factor for boosting economic growth (Karunakaran N and Rema R, 2018).

\section{Materials and Methods}

Kumar P (2011) studied the foreign investment flows through automobile sector with special reference to passenger cars. Azhar, S and Marimuthu, K.N. (2012) analyzed the need of the retail community to invite FDI in retailing. Devajit (2012) conducted the study to find out the impact of foreign direct investments on Indian economy and concluded that Foreign Direct Investment (FDI) as a strategic component of investment for its sustained economic growth. Agarwal S, et al, (2012) studied the relation of foreign investment and Indian retail business. Abhishek Vijaykumar Vyas (2015) observed that FDI is an important stimulus for the economic growth of India. The study is based on secondary data collected from various Reports of Ministry of commerce and industry, Government of India, Reserve Bank of India Bulletins and Report of India Brand Equity Foundation.

\section{Results and Discussion \\ Sources of FDI}

The main sources of FDI are MNCs which alone contribute about 95 percent. They are investing to achieve internalisation, localisation and ownership advantages and penetrate in the foreign market with subsidiaries abroad.

Types of FDI It includes;

1. Horizontal FDI: A firm duplicates its home country based activities in a host country through FDI.

2. Vertical FDI: A firm through FDI performs value adding in upstream or downstream in a host country.

3. Platform FDI: A home country makes investment to a host country for the purpose of exporting to a third country.

\section{FDI Flows to India}

During 1990-91 foreign capital flows to India was Rs.174 crore. In 2000-01 it was 4029 US\$ Million, during 2010-11, 34847 US\$ Million and in 2019-20 it reached at 73455 US\$ Million (Table 1).

Table 1: FDI flows in India from 2000-01 to 2019-20 (Amount US\$ Million)

\begin{tabular}{|c|c|c|c|c|c|c|}
\hline \multirow[t]{2}{*}{ Year } & \multicolumn{2}{|c|}{ Equity } & \multirow{2}{*}{$\begin{array}{c}\text { Re-invested } \\
\text { earnings }\end{array}$} & \multirow{2}{*}{$\begin{array}{l}\text { Other } \\
\text { capital }\end{array}$} & \multirow{2}{*}{$\begin{array}{c}\text { Total } \\
\text { FDI } \\
\text { Flows }\end{array}$} & \multirow{2}{*}{$\begin{array}{c}\text { Percentage } \\
\text { growth over } \\
\text { previous year (in } \\
\text { US\$ terms) }\end{array}$} \\
\hline & $\begin{array}{l}\text { FIPB Route/ RBI's } \\
\text { Automatic Route/ } \\
\text { Acquisition Route }\end{array}$ & $\begin{array}{l}\text { Equity capital of } \\
\text { unincorporated } \\
\text { bodies }\end{array}$ & & & & \\
\hline $2000-01$ & 2339 & 61 & 1350 & 279 & 4029 & ----- \\
\hline $2001-02$ & 3904 & 191 & 1645 & 390 & 6130 & (+) 52 \\
\hline
\end{tabular}




\begin{tabular}{|c|c|c|c|c|c|c|}
\hline $2002-03$ & 2574 & 190 & 1833 & 438 & 5035 & $(-) 18$ \\
\hline $2003-04$ & 2197 & 32 & 1460 & 633 & 4322 & $(-) 14$ \\
\hline $2004-05$ & 3250 & 528 & 1904 & 369 & 6051 & $(+) 40$ \\
\hline $2005-06$ & 5540 & 435 & 2760 & 226 & 8961 & $(+) 48$ \\
\hline $2006-07$ & 15585 & 896 & 5828 & 517 & 22826 & $(+) 155$ \\
\hline $2007-08$ & 24573 & 2291 & 7679 & 300 & 34843 & $(+) 53$ \\
\hline $2008-09$ & 31364 & 702 & 9030 & 777 & 41873 & $(+) 20$ \\
\hline $2009-10$ & 25606 & 1540 & 8668 & 1931 & 37745 & $(-) 10$ \\
\hline $2010-11$ & 21376 & 874 & 11939 & 658 & 34847 & $(-) 08$ \\
\hline $2011-12$ & 34833 & 1022 & 8206 & 2495 & 46556 & $(+) 34$ \\
\hline $2012-13$ & 21825 & 1059 & 9880 & 1534 & 34298 & $(-) 26$ \\
\hline $2013-14$ & 24299 & 975 & 8978 & 1794 & 36046 & $(+) 5$ \\
\hline $2014-15$ & 30933 & 978 & 9988 & 3249 & 45148 & $(+) 25$ \\
\hline $2015-16$ & 40001 & 1111 & 10413 & 4034 & 55559 & $(+) 23$ \\
\hline $2016-17$ & 43478 & 1223 & 12343 & 3176 & 60220 & $(+) 8$ \\
\hline $2017-18$ & 44857 & 664 & 12542 & 2911 & 60974 & $(+) 1$ \\
\hline $2018-19$ & 44366 & 689 & 13672 & 3274 & 62001 & $(+) 2$ \\
\hline $2019-20$ & 49977 & 1226 & 14052 & 8200 & 73455 & $(+) 18$ \\
\hline
\end{tabular}

Source: Report of Ministry of Commerce and Industry, GOI

\section{Sectoral distribution of FDI in India}

The sectoral distribution of FDI inflow has also been changed over the years. In 1970s, half of the total inflow of FDI was in manufacturing sector and a quarter each in primary and tertiary sectors. Recently, the proportion of FDI on tertiary sector has increased. The share on primary sector has declined and that on manufacturing sector has reduced slightly, but it still occupies the major share of FDI. Presently the share of service sector occupies the first position, computer software and hardware in second, followed by telecommunication and trading sector (Table 2).

Table 2: Sectoral distribution of FDI in India (Amount in Rs. Crores (in US\$ Million))

\begin{tabular}{|c|c|c|c|c|c|c|}
\hline Rank & Sectors & $\begin{array}{l}\text { 2017-18 } \\
\text { (April - } \\
\text { March) }\end{array}$ & $\begin{array}{l}\text { 2018-19 } \\
\text { (April - } \\
\text { March) } \\
\end{array}$ & $\begin{array}{l}\text { 2019-20 } \\
\text { (April - } \\
\text { March) } \\
\end{array}$ & $\begin{array}{c}\text { Cumulative Inflows } \\
\text { (April, 00 - March, } \\
\text { 20) } \\
\end{array}$ & $\begin{array}{c}\text { Percentage to total } \\
\text { Inflows (in terms of } \\
\text { US\$) } \\
\end{array}$ \\
\hline 1. & Services sector & $\begin{array}{l}43,249 \\
(6,709) \\
\end{array}$ & $\begin{array}{l}63,909 \\
(9,158) \\
\end{array}$ & $55,429(7,854)$ & $471,730(82,003)$ & 17 \\
\hline 2. & $\begin{array}{l}\text { Computer Software \& } \\
\text { Hardware }\end{array}$ & $\begin{array}{l}39,670 \\
(6,153)\end{array}$ & $\begin{array}{l}45,297 \\
(6,415)\end{array}$ & $54,250(7,673)$ & $276,006(44,911)$ & 10 \\
\hline 3 & Telecommunications & $\begin{array}{l}39,748 \\
(6,212)\end{array}$ & $\begin{array}{l}18,337 \\
(2,668)\end{array}$ & $30,940(4,445)$ & $219,189(37,271)$ & 8 \\
\hline 4. & Trading & $\begin{array}{l}28,078 \\
(4,348) \\
\end{array}$ & $\begin{array}{l}30,963 \\
(4,462) \\
\end{array}$ & $32,406(4,574)$ & $176,005(27,595)$ & 6 \\
\hline 5. & $\begin{array}{l}\text { Construction development: } \\
\text { townships, housing, built-up } \\
\text { infrastructure and construction- } \\
\text { development projects }\end{array}$ & $\begin{array}{l}3,472 \\
(540)\end{array}$ & $\begin{array}{l}1,503 \\
(213)\end{array}$ & $4,350(617)$ & $129,964(25,662)$ & 5 \\
\hline 6. & Automobile industry & $\begin{array}{l}13,461 \\
(2,090) \\
\end{array}$ & $\begin{array}{l}18,309 \\
(2,623) \\
\end{array}$ & $19,753(2,824)$ & $143,742(24,211)$ & 5 \\
\hline 7. & $\begin{array}{l}\text { Chemicals (other than } \\
\text { fertilizers) }\end{array}$ & $\begin{array}{c}8,425 \\
(1,308)\end{array}$ & $\begin{array}{l}13,685 \\
(1,981)\end{array}$ & $7,492(1,058)$ & $98,554(17,639)$ & 4 \\
\hline 8. & $\begin{array}{l}\text { Construction (infrastructure) } \\
\text { activities }\end{array}$ & $\begin{array}{l}17,571 \\
(2,730)\end{array}$ & $\begin{array}{l}15,927 \\
(2,258)\end{array}$ & $14,510(2,042)$ & $108,383(16,847)$ & 4 \\
\hline 9. & Drugs \& Pharmaceuticals & $\begin{array}{c}6,502 \\
(1,010) \\
\end{array}$ & $\begin{array}{l}1,842 \\
(266)\end{array}$ & $3,650(518)$ & $87,814(16,501)$ & 4 \\
\hline 10. & Hotel \& Tourism & $\begin{array}{c}7,279 \\
(1,132)\end{array}$ & $\begin{array}{c}7,590 \\
(1,076)\end{array}$ & $21,060(2,938)$ & $91,779(15,289)$ & 3 \\
\hline
\end{tabular}

Source: Report of Ministry of Commerce and Industry, GOI

\section{Share of Top 10 investing countries FDI inflows}

Foreign Direct Investment inflows in to India increased by 14 percent in the financial year 2019-2020. Major portion of FDI in India is from Mauritius and Singapore followed by Netherlands, Japan, USA and UK (Table 3). 
Table 3: Share of top 10 investing countries FDI inflows in India (Amount in Rs. Crores (in US\$ Million)

\begin{tabular}{|l|l|c|c|c|c|c|}
\hline Rank & Country & $\begin{array}{c}\mathbf{2 0 1 7 - 1 8} \text { (April - } \\
\text { March) }\end{array}$ & $\begin{array}{c}\mathbf{2 0 1 8 - 1 9 ( A p r i l ~ - ~} \\
\text { March) }\end{array}$ & $\begin{array}{c}\mathbf{2 0 1 9 - 2 0} \text { (April - } \\
\text { March) }\end{array}$ & $\begin{array}{c}\text { Cumulative Inflows } \\
\text { (April, 00 - } \\
\text { March,20) }\end{array}$ & $\begin{array}{c}\text { Percentage to } \\
\text { total Inflows (in } \\
\text { terms of US \$) }\end{array}$ \\
\hline 1. & Mauritius & $102,492(15,941)$ & $57,139(8,084)$ & $57,785(8,241)$ & $795,941(142,710)$ & 30 \\
\hline 2. & Singapore & $78,542(12,180)$ & $112,362(16,228)$ & $103,615(14,671)$ & $609,562(97,670)$ & 21 \\
\hline 3. & Netherlands & $18,048(2,800)$ & $27,036(3,870)$ & $46,071(6,500)$ & $208,322(33,852)$ & 7 \\
\hline 4. & Japan & $10,516(1,633)$ & $20,556(2,965)$ & $22,774(3,226)$ & $196,105(33,499)$ & 7 \\
\hline 5. & U.s.a. & $13,505(2,095)$ & $22,335(3,139)$ & $29,850(4,223)$ & $176,222(29,779)$ & 6 \\
\hline 6. & U.k. & $5,473(847)$ & $9,352(1,351)$ & $10,041(1,422)$ & $150,411(28,211)$ & 6 \\
\hline 7. & Germany & $7,245(1,124)$ & $6,187(886)$ & $3,467(488)$ & $68,944(12,196)$ & 3 \\
\hline 8. & Cyprus & $2,680(417)$ & $2,134(296)$ & $6,449(879)$ & $57,993(10,748)$ & 2 \\
\hline 9. & France & $3,297(511)$ & $2,890(406)$ & $13,686(1,896)$ & $50,511(8,539)$ & 2 \\
\hline 10. & $\begin{array}{l}\text { Cayman } \\
\text { islands }\end{array}$ & $7,932(1,237)$ & $7,147(1,008)$ & $26,397(3,702)$ & $49,848(7,536)$ & 2 \\
\hline
\end{tabular}

Source: Report of Ministry of Commerce and Industry, GOI

\section{State wise classification of FDI in India}

In India most FDI investment is attracted by the state Maharashtra. 30 percent of the FDI flows in India are in the state of Maharashtra followed by Karnataka, Delhi and Gujarat (Table 4).

Table 4: State wise classification of FDI in India (Amount in Rs. Crores (in US\$ Million)

\begin{tabular}{|l|l|c|c|}
\hline S. No. & State & Cumulative Inflows (March, 2020) & Percentage to total Inflows (in terms of US\$) \\
\hline 1 & Maharashtra & $52,073(7,263)$ & 30 \\
\hline 2 & Karnataka & $30,746(4,289)$ & 18 \\
\hline 3 & Delhi & $28,487(3,973)$ & 17 \\
\hline 4 & Gujarat & $18,964(2,591)$ & 11 \\
\hline 5 & Jharkhand & $13,208(1,852)$ & 8 \\
\hline 6 & Tamilnadu & $7,230(1,006)$ & 4 \\
\hline 7 & Haryana & $5,198(726)$ & 3 \\
\hline 8 & Telangana & $4,865(680)$ & 3 \\
\hline 9 & Uttar Pradesh & $1,738(243)$ & 1 \\
\hline 10. & Andhra Pradesh & $1,476(206)$ & 0.9 \\
\hline
\end{tabular}

Source: Report of Ministry of Commerce and Industry, GOI

\section{Conclusion}

There has been a generous flow of FDI in India since 1991. It has become the second fastest growing economy of the world. India has substantially increased its list of source countries in the post liberalisation era. The country has signed a number of bilateral and multilateral trade agreements with developed and developing nations. The Economic reform process started in 1991 helped in creating a conducive and healthy atmosphere for foreign investors and thus resulting in substantial amount of FDI inflows in India.

\section{Source of Funding}

None.

\section{Conflict of Interest}

None.

\section{References}

1. Abhishek Vijaykumar Vyas. An Analytical Study of FDI in India (2000-2015). Int J Sci Res Publications. 2015;5(10):198.

2. Aggrawal S, Singla A, Aggrawal R. Foreign direct investment in India. Int J Comput Eng Manag. 2012;15(5):93-105.

3. Azhar S, Marimuthu KN. An overview of foreign direct Investment in India. Int J Multidiscip Manag Studies.
2012;2(1):202-14.

4. Devajit M. Impact of foreign direct investment on Indian economy. Res J Manag Sci. 2012;1(2):29-31.

5. Karunakaran N, Rema R. Role of Foreign Direct Investment in Research and Development of Pharmaceutical Industries in India. Food Sci Nutr Technol. 2018;3(6):1-4.

6. Kumar P. FDI in India and its impact-A critical evaluation. VRSD Int J Business Manag Res. 2011;1(3):185-96.

7. Rema R, Karunakaran N. Trend and Determinants of NonPerforming Assets in India. J Manag Resd Anal. 2019;6(4):174-7.

How to cite this article: Sebastian SM, Karunakaran N. Trend and pattern of international capital flows in India. J Manag Res Anal. 2020;7(4):151-3. 